\title{
A "nobreza agrária das Terras Frias": análises preliminares das estratégias políticas, sociais e econômicas de Dimas Ferreira Pedrosa (Nova Friburgo/RJ - Séc. XIX)
}

\section{The "Terras Frias Landed Gentry": preliminary analysis of political, social and economic strategies of Dimas Ferreira Pedrosa (Nova Friburgo/RJ - 19th Century)}

\author{
Gabriel Almeida Frazão* \\ https://orcid.org/0000-0001-7450-2810
}

\begin{abstract}
Resumo
O artigo tem como objetivo caracterizar o arranjo produtivo local das "Terras Frias", voltado para o abastecimento de gêneros alimentícios do mercado interno, na segunda metade do século XIX. Para tal, tomando como referencial o debate sobre abastecimento e estudos regionais iniciado pela história agrária e os pressupostos da micro-história, aborda-se a trajetória de um importante agente local: Dimas Ferreira Pedrosa. Utilizando-se de jornais de época, documentação cartorial e eclesiástica, entende-se que, por meio da análise das suas estratégias políticas, econômicas e sociais, seja possível escrutinar não somente as características agrícolas, como os valores que orientaram as ações de grupos abastados da Província Fluminense, no Brasil Imperial. Por fim, o texto propõe uma discussão sobre as possibilidades de classificação socioeconômica de um sujeito que foi político, negociante, fazendeiro, e senhor de escravos que, apesar de não fazer parte da nobreza titulada, viveu e/ou procurou viver como ela.
\end{abstract}

Palavras-chaves: história agrária e regional; micro-história; Brasil Império: Nova Friburgo (RJ)

\begin{abstract}
The goal of this research is to describe local and internal food production arrangement in Terras Frias during the second half of the nineteenth century. To do so, debates started by agricultural history on local supplies and regional studies as well as assumptions of microhistory were taken as a reference to approach a relevant local agente: Dimas Ferreira Pedrosa. It was
\end{abstract}

${ }^{*}$ Doutor em Sociologia Rural (CPDA/ UFRRJ). Professor do Instituto Federal Fluminense e Pesquisador do INCT Proprietas. E-mail: gabrielalmeidafrazao@gmail.com 
analysed his political, economic and social strategies through periodicals, offical registry and ecclesiastical documents. It may be possible, thereby, to scrutinize agricultural characteristics and values that guided wealthy groups in Fluminense Province in Imperial Brazil. Finally, it is put forward a discussion about his possible socioeconomic classification. Although being a politician, dealer, farmer, and slave owner Dimas Ferreiras Pedrosa was not part of the titled nobility. However he lived and/or sought to live like one of them.

Keywords: agricultural and regional history; microhistory; Imperial Brazil; Novas Friburgo (RJ)

\section{Introdução}

No Brasil, desde o final da década de 1970, veio se consolidando uma série de estudos sobre o universo rural e seus desdobramentos que podem ser definidos como pertencentes a uma "história agrária, ou história social da agricultura". ${ }^{1}$ Linhares e Silva, em 1981, anunciavam que os analistas do rural teriam que lidar com a complexidade da organização das relações de produção e do desenvolvimento das forças produtivas ao longo do território brasileiro. ${ }^{2}$ Somente assim, seria possível revelar a "face oculta de uma sociedade fundamentalmente agrária, até um passado bem recente", ${ }^{3}$ cabendo ao pesquisador encarar o seu objeto, atentamente, "sob a ótica do microscópio", para entender hierarquias e mentalidades que fogem das concepções dos censos e de critérios globais. ${ }^{4}$

A defesa de um olhar minucioso sobre o mundo rural fez com que os autores percebessem vários ângulos e objetos que poderiam ser explorados pela história da agricultura, tais como: aspectos da produção e das trocas regionais; mecanismos de dominação política; e cotidiano da população (lazer, crenças, costumes, doenças). Como cada um deles exigiriam métodos e fontes distintos, Linhares e Silva destacaram a impossibilidade de se dar uma receita aos estudiosos, ratificando a defesa dos recortes regionais, enquanto

\footnotetext{
${ }^{1}$ MOTTA, Márcia Maria Menendes. “História Agrária” In MOTTA, Márcia Maria Menendes (Org.). Dicionário da Terra. Rio de Janeiro: Civilização Brasileira, 2005, p. 239-240

${ }^{2}$ LINHARES, Maria Yeda e SILVA, Francisco Carlos Teixeira. História da Agricultura Brasileira: combates e controvérsias. São Paulo: Brasiliense, 1981. O debate já havia se iniciado anos antes, com Ciro Cardoso. Ver: CARDOSO, Ciro Flamarion Santana. Agricultura, escravidão e capitalismo. Petrópolis: Vozes, 1979.

${ }^{3}$ LINHARES e SILVA, op. cit., p.14

${ }^{4}$ Ibidem, p. 103
} 
procedimento capaz de “desmascarar pressupostos de uma história (...) elaborada a partir dos centros de decisão nacional". ${ }^{5}$ Esse pensamento foi colocado em prática por Silva que, ao tratar do Sertão do São Francisco, procurou romper as concepções generalizantes sobre o Nordeste Brasileiro. O "Sertão" foi concebido como uma região, que foi surgindo e se delineando "a cada fase de aperfeiçoamento da pesquisa". ${ }^{6}$ Em síntese, para os autores, a "história regional é a opção que deverá se cruzar com a escolha da história agrária".?

Os trabalhos dos dois historiadores deram aporte a inúmeros outros estudos que, ao longo das últimas duas décadas, trataram do mundo rural em diversas localidades, temporalidades e temáticas. ${ }^{8}$ Tendo como base a relação entre a o recorte regional e a história agrária, o texto aqui apresentado pretende examinar uma porção rural do município de Nova Friburgo, parte da Província Fluminense, na segunda metade do século XIX: as chamadas "Terras Frias".

Nas últimas décadas, a cidade serrana têm sido objeto de muitos trabalhos historiográficos. Destaca-se, em vários deles, a preocupação em redimensionar o papel da colonização suíça, ressaltando a atuação de outros grupos sociais menos enaltecidos pelas narrativas políticas oficiais. ${ }^{9}$ Se por

\footnotetext{
${ }^{5}$ A dissertação de mestrado, defendida em 1981, foi recentemente publicada. SILVA, Francisco Carlos Teixeira da. A formação social da miséria: Porto da Folha no sertão do São Francisco (1820-1920). $1^{\circ}$ Ed. Rio de Janeiro: Autografia, 2018, p. 103-104.

${ }^{6}$ Ibidem, p. 23

${ }^{7}$ Ibidem.

${ }^{8}$ Atendo-se, apenas, a primeira geração de historiadores que deram prosseguimento aos estudos de Maria Yeda Linhares e Francisco Carlos Teixeira da Silva, destacam-se: CASTRO, Hebe Maria Mattos de. Ao Sul da História: lavradores pobres na crise do trabalho escravo. Rio de Janeiro: Editoria FGV, 2009; FRAGOSO, João. Homens de Grossa Ventura: acumulação e hierarquia na praça mercantil do rio de Janeiro (1790-1830). Rio de Janeiro/FAPERJ/Jorge Zahar Editor, 2008; MOTTA, Márcia Maria Menendes. Pelas Bandas d'Além: fronteira fechada e arrendatários escravistas em uma região policultora. 1989. Dissertação (Mestrado em História) - Universidade Federal Fluminense, Niterói; MOTTA, Márcia Maria Menendes. MOTTA. Nas fronteiras do poder: conflito e direito à terra no Brasil do século XIX. Niterói, RJ: EdUFF, 2008; FARIA, Sheila de Castro. Terra e trabalho em Campos dos Goitacases (1850-1920). 1986. Dissertação (Mestrado em História) - Universidade Federal Fluminense, Niterói; FARIA, Sheila de Castro. A colônia em movimento: fortuna e família no cotidiano colonial. Rio de Janeiro: Nova Fronteira, 1998;

${ }^{9}$ Dentre eles, destacam-se: PEDRO, José Carlos. A Colônia do "Morro Queimado": suiços e luso-brasileiros na Freguesia de São João Batista de Nova Friburgo (1820-31). 1999. Dissertação (Mestrado em História) - Universidade Federal Fluminense, Niterói (RJ); MAYER. Jorge Miguel; ARAÚJO, João Raimundo (Orgs.) Teia Serrana: formação histórica de Nova Friburgo. Rio de Janeiro: Editora ao livro Técnico, 2003; ARAÚJO. João Raimundo. A construção do mito da suiça (1910-1960). 2003. Tese (Doutorado em História) - Universidade Federal Fluminense, Niterói (RJ); FERREIRA, Marieta Moraes. História de Familia: casamentos, alianças e fortunas. Rio de Janeiro: Léo Christiano Editorial, 2008; MARRETTO, Rodrigo Marins. A escravidão velada: senhores e escravos na formação da Vila de São João Batista de Nova Friburgo (1820-1850). Rio de Janeiro: Revan, 2018; ARAÚJO, João Raimundo de; LO BIANCO, Regina; COSTA, Ricardo Rosa da Gama (Org.) Teia Serrana II: novos temas e novas abordagens. Nova Friburgo: Marca Gráfica Editora, 2019; MARRETTO, Rodrigo Marins. 0 opulento
} 
um lado, é possível afirmar que a perspectiva de uma história regional se faz presente nesta historiografia, por outro, são poucos os trabalhos que, de alguma maneira, relacionam-se com as discussões da história agrária. Nota-se que os estudos não se dedicaram à região em questão, concentrando-se em outras porções do território e/ou sobre seu relacionamento com Cantagalo, grande produtor de café. ${ }^{10}$

As discussões e resultados apresentados nestas páginas fazem parte de uma pesquisa maior, que visa à caraterização minuciosa do arranjo produtivo local das "Terras Frias”, na segunda metade do século XIX e no início do XX. Devido a dificuldades de acesso à documentação utilizada para a construção de análises seriais e quantitativas, optou-se por uma análise intensiva e mais qualitativa das ações de alguns agentes sociais da localidade. ${ }^{11} \mathrm{Em}$ um primeiro momento, com base em relatos orais e catalogação de fazendas antigas, identificaram-se algumas famílias ali presentes desde os oitocentos. Em uma perspectiva de média duração, realizou-se uma análise explanatória inicial de vários documentos (mapas, jornais, documentos administrativos), o que gerou uma lista nominativa, que, por fim, foi comparada com os nomes dos fazendeiros, negociantes e lavradores listados no Almanak Laemmert do município de Nova Friburgo. Esses nomes constituíram as "estrela[s] de primeira grandeza", ou seja, serviram de porta de entrada para o mundo que se queria conhecer. ${ }^{12}$ Desde então, por meio da metodologia da micro-história, ${ }^{13}$ aprecia-se a região,

capitalista: café e escravidão na formação do patrimônio familiar do Barão de Nova Friburgo. (1829-1873). 2019. Tese (Doutorado em História) - Universidade Federal Fluminense, Niterói (RJ); COSTA, Ricardo Gama da Costa e GUIMARÃES, Fernanda. (Orgs.) Memórias do legislativo Friburguense: 200 anos de história da Câmara Municipal. Nova Friburgo: Gráfica Associação de Pais e Amigos dos Excepcionais, 2020.

${ }_{10}$ MAYER, Jorge Miguel. Raízes e crises do mundo caipira: o caso de Nova Friburgo. 2003. Tese (Doutorado em História) - Universidade Federal Fluminense, Niterói (RJ). Entende-se este trabalho como o pioneiro nesta temática da história friburguense. Outros também abordaram a questão agrária: LISBOA, Edson Castro. "Café e escravidão em Nova Friburgo no século XIX" In: MAYER e ARAÚJO (Orgs.) Teia Serrana... op. cit. MARRETTO, A escravidão velada... op. cit.; MARRETO, O opulento capitalista...op. cit.; FARIA. Sheila de Castro. "Ouro, porcos, escravos e café: as origens das fortunas oitocentistas em São Pedro de Cantagalo, Rio de Janeiro (últimas décadas do século XVIII e primeiras do XIX)”. Anais do Museu Paulista. São Paulo, Nova Série, v.26, 2018, p. 1-23.

${ }^{11} \mathrm{Um}$ procedimento já consolidado para a análise regional se baseia no exame quantitativo e serial da localidade em questão. Nesse sentido, além de se buscar dados gerais em publicações, como censos e outras listas, utilizam-se os inventários como instrumento para caracterização econômica e tipificação dos proprietários. A partir, então, da construção do cenário geral é que, muitas vezes, parte-se para exames mais individualizados. Não se nega aqui a validade desta metodologia, base de muitos trabalhos com os quais se dialoga, porém, a opção por um caminho "inverso" se dá, também, pelo fato de os inventários de Nova Friburgo não se encontrarem mais na cidade, tendo sido alocados em um arquivo na capital, onde o sistema de localização e consulta (não informatizado e sem descrição para o pesquisador) dificulta o acesso. ${ }^{12}$ BARTH, Fredrik. Scale and Social Organization. Oslo: Universitetforlaget, 1978.

${ }^{13}$ GINZBURG, Carlo. Mitos, emblemas, sinais: morfologia e história. São Paulo: Companhia das 
que vai se delineando a partir do avanço da pesquisa, na qual o estudo de uma personagem e suas relações levam à identificação de outros nomes, como em um movimento contínuo de ligação de pontos de uma rede.

Sendo assim, apresenta-se a trajetória do negociante e fazendeiro Dimas Ferreira Pedrosa, entendendo que, a partir dela, é possível conhecer traços da vida política, econômica e social de uma porção pouco apreciada do Brasil Imperial. O período estudado se circunscreve do momento em que esse sujeito inicia sua atividade comercial (1843) até os anos seguintes da sua morte (1886). Para tal, valeu-se das seguintes fontes: periódicos de época; documentação administrativa; registros cartoriais e eclesiásticos. 0 texto se divide em cinco seções. A primeira, de caráter introdutório, e que, agora se encerra, apresentou, em linhas gerais, as perspectivas que orientaram o estudo, os seus objetivos, bem como a metodologia empregada e as fontes utilizadas. A segunda, dando prosseguimento a outros trabalhos realizados, caracteriza a região a partir dos aspectos econômicos, administrativos, sociais e climáticos. As três últimas se dedicam a analisar dados políticos, econômicos e sociais da vida de Dimas Ferreira Pedrosa. Por meio deles, e diante da complexidade dos valores que orientaram as ações de Pedrosa, aventa-se a possibilidade de ele ser visto como representante de uma "nobreza agrária" local.

\section{As "Terras Frias": região de cultivo, de criação e de conexão com mercados regionais}

As chamadas "Terras Frias" ainda são uma área pouco estudada pela historiografia dedicada ao interior fluminense. Além de trabalhos anteriores já desenvolvidos por este autor, mais um discute essa porção do Estado do Rio de Janeiro. ${ }^{14}$ Ambos, em linhas gerais, concordam que essas terras (de elevada altitude e clima frio) estavam dispostas, em grande parte, ao longo do que hoje é a Rodovia Estadual 130 (Estrada Friburgo-Teresópolis), constituindo-se enquanto importante centro produtor de gêneros agrícolas destinados a

Letras, 1989; LEVI, Giovanni. A herança imaterial: trajetória de um exorcista no Piemonte do século XVII. Rio de Janeiro: Civilização Brasileira, 2000; REVEL, Jacques (Org.). Jogos de escala: a experiência da microanálise. Rio de Janeiro: Ed. FGV, 1998.

${ }^{14}$ FRAZÃO, Gabriel Almeida. Um negociante das -Terras Frias-: uma análise das estratégias de aquisição fundiária do português Antonio José Mendes (Nova Friburgo, 1860-1914). REVISTA MARACANAN, v. 1, p. 59-82, 2020; FRAZÃO, Gabriel Almeida. "Caminhos e descaminhos de um político local: considerações sobre as estratégias e a trajetória de Dimas Ferreira Pedrosa (Nova Friburgo - 1844-1882).”. In. COSTA, e GUIMARÃES (Orgs). Memórias do legislativo... op. cit.,, p. 75-95. CORRÊA, Maria Janaína Botelho e SANTOS, Selmo de Oliveira. "Terras Frias: um ensaio sobre a reforma agrária na fazenda Rio Grande." In. ARAÚJO; LO BIANCO; COSTA, (Orgs.) Teia Serrana II...op. cit., p. 105-129. 
mercados locais e à capital do Estado. Ainda que, devido à baixa temperatura, elas não fossem tão propícias ao cultivo de café, principal produto de exportação do século XIX, gêneros como milho, feijão e batata movimentavam a economia local. As pesquisas também apontam para a importância da criação de mulas e dos tropeiros que, por meio das estradas locais, transportavam as mercadorias e faziam daquele espaço uma região de passagem, de encontros e de oportunidades. ${ }^{15}$

Contudo, há divergências sobre alguns pontos relevantes acerca da delimitação do território. Corrêa e Santos, em sua análise sobre uma das famílias latifundiárias locais, entendem as chamadas "Terras Frias" como sinônimo do território da Freguesia de Sebastiana, criada em 1862, e que pertenceu a Nova Friburgo até as primeiras décadas do século XX. Sendo assim, se por um lado, os autores reconhecem que, mesmo após a perda da freguesia para a vizinha Teresópolis, Nova Friburgo, já no século XX, passou a ter um Distrito chamado de "Terras Frias", ${ }^{16}$ por outro lado, constroem toda a sua análise com base nos dados referentes somente a Sebastiana, tais como o Censo de 1872. Parece haver uma certa incongruência no exame, uma vez que não fica claro se: (i) no início do século XX, aquele território, com todas as suas características, deixou de fazer parte de Friburgo integralmente; (ii) na divisão territorial, uma parte ficou com este município, o que explicaria a existência de um novo distrito com o mesmo nome; e ainda se (iii) os autores não teriam feito uma sobreposição entre uma unidade administrativa (o distrito de Sebastiana) com uma área mais abrangente, definida por suas características de clima e de relevo. Aqui está a principal divergência conceitual entre os trabalhos.

Aborda-se aqui as chamadas "Terras Frias" sob um outro ponto de vista teórico-metodológico. A partir de um diálogo com os autores ligados

\footnotetext{
${ }^{15}$ Existem alguns trabalhos, ligados a outras áreas de conhecimento, que analisaram esse território fluminense na sua contemporaneidade. DÁLIA, Jaqueline de Moraes Thurler. Aspectos fonéticos da variação linguística-identitárias das comunidades rurais do $3^{\circ}$ Distrito de Nova FriburgoRJ. A cor das Letras, Feira de Santana (BA), v. 19, n. Especial, p. 40-63, mar. 2018. Disponível em: http://periodicos.uefs.br/index.php/acordasletras/article/view/2858. Acesso em: 20 agosto de 2020; FRAZÃO, Gabriel Almeida. "A Serviço da Formação do Jovem Rural”: Desafios e Contradições na Atuação do CEFFA CEA Rei Alberto I Como Agente do Desenvolvimento do Meio. 2015. Tese (Doutorado em Sociologia Rural) - Programa de Pós-graduação de Ciências Sociais em Desenvolvimento, Agricultura e Sociedade, Universidade Federal Rural do Rio de Janeiro, Seropédica (RJ); ${ }^{16}$ CORRÊA e SANTOS, Terras Frias... op. cit., p. 105-120. Sebastiana deixou de fazer parte de Nova Friburgo em 1901 (Decreto-lei n..517 de 7 de dezembro), passando a pertencer ao 3ํㅡㄹistrito de Teresópolis. FÉO, Roberto. Raízes de Teresópolis: outras histórias e outras coisas. Teresópolis: Zen, 2010, p. 175. Somente em 1924, foi criado do Distrito das Terras Frias, que, em 1938, teve seu nome alterado para Campo do Coelho. PRÓ-MEMÓRIA. Nova Friburgo: notas e informações. Nova Friburgo, RJ: Prefeitura Municipal de Nova Friburgo, 1985, p. 10-11.
} 
à história da agricultura, caracteriza-se o território a partir do conceito de região. Baseando-se, primeiramente, em Bourdieu, ${ }^{17}$ vale ressaltar que os recortes regionais são frutos das representações mentais dos agentes sociais; que as divisões administrativas não podem ser naturalizadas; e que, cabe ao estudioso, buscar as relações sociais que propiciaram a existência de uma regionalidade. Essa perspectiva é corroborada por Teixeira e Linhares. Os dois autores chamaram a atenção para o fato de o historiador não poder se limitar às amarras da divisão administrativa, percebendo a utilidade de um olhar mais atento sobre a organização social e econômica na delimitação da área estudada. ${ }^{18}$ Essas premissas, aliadas a procedimentos da micro-história, tais como a variação de escalas e o exame da trajetória de agentes sociais, possibilitaram uma melhor compreensão do espaço. ${ }^{19} \mathrm{~A}$ análise realizada das ações do proprietário local, o português Antonio José Mendes, demonstrou que pessoas de outras duas freguesias interagiam e tinham atividades econômicas, inclusive por conta do relevo e do clima, semelhantes àquelas existentes na Freguesia de Sebastiana. ${ }^{20}$ Diante dos dados, "Terras Frias" são compreendidas aqui como porções de três freguesias friburguenses da segunda metade do século XIX (Ver Figura 1): São João Batista (sede da Vila); Nossa Senhora de Conceição do Paquequer (Sumidouro) e Sebastiana. ${ }^{21}$

\footnotetext{
${ }^{17}$ BOURDIEU, Pierre. O poder simbólico. Rio de Janeiro: Bertrand, 2010. OLIVEIRA, Victor Pereira. Repensando o rural sob o prisma das ruralidades, em Nova Friburgo, RJ. Curitiba: CRV, 2011.

${ }^{18}$ Além das obras citadas ao longo do trabalho, destaca-se, para essa discussão: SILVA, Francisco Carlos Teixeira da; LINHARES, Maria Yedda. Região e história agrária. Estudos Históricos, Rio de Janeiro, v. 8, n. 15, p. 17-26, 1995.

${ }^{19}$ GINZBURG, op. cit..; LEVI, op. cit..; REVEL (Org.), op. cit.

${ }^{20}$ FRAZÃO, Um negociante... op. cit., p. 59-82.

${ }^{21} \mathrm{~A}$ partir de uma perspectiva de média duração, a área de interseção, bem próxima do centro da Vila de Friburgo e não tão distante da capital do Império e do território mineiro, é composta por: parcelas do atual $3^{2}$ Distrito de Nova Friburgo, do município de Sumidouro, também com clima mais frio, e de Teresópolis. Elas, ao longo dos séculos XIX e XX, constituíram-se enquanto uma região de produção de gêneros de abastecimento e de criação de animais. Ibidem, p. 59-82.
} 
Figura 1: Delimitação da Região das "Terras Frias"

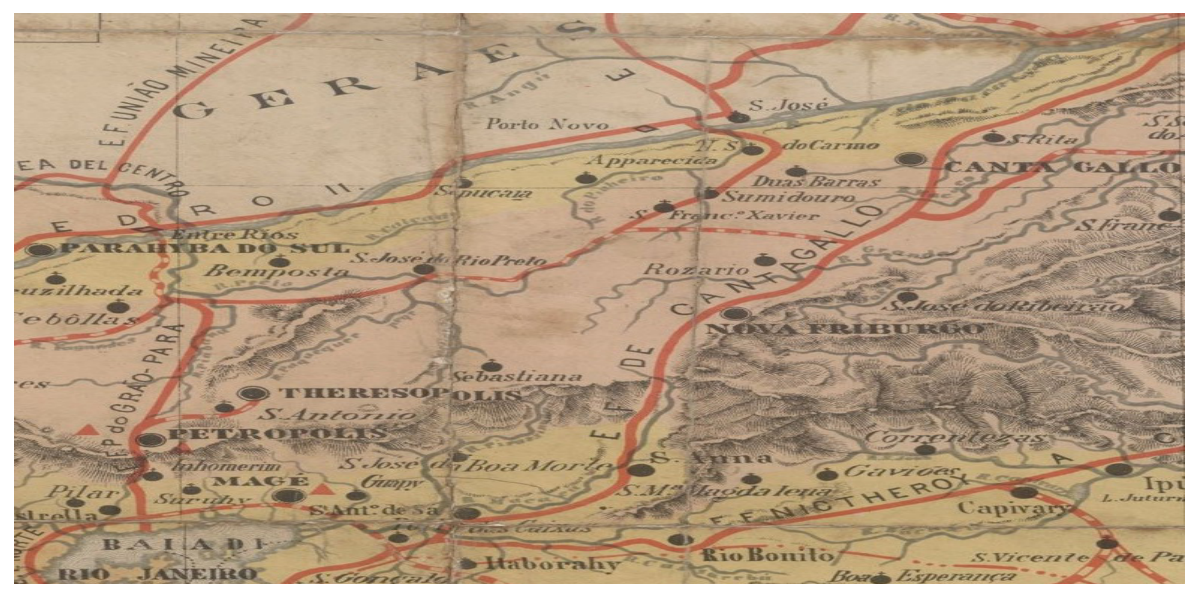

Fonte: Recorte feito pelo autor de Mapa da Província do Rio de Janeiro (1887). ${ }^{22}$

Ademais, por meio da apreciação dos dados do Censo de 1872 das três unidades eclesiásticas, evidenciou-se como o território recebeu grande quantitativo de imigrantes portugueses. A trajetória do fazendeiro foi entendida à luz de um grande fluxo migratório, que, desde meados do século XIX, atraiu lusitanos para Nova Friburgo. Alguns deles foram figuras ilustres do Império do Brasil, como o Antonio Clemente Pinto, o $1^{\circ}$ Barão de Nova Friburgo, que possuía na área uma "fazenda de criar". ${ }^{23}$

Neste momento, para o avanço do debate, cabe destacar a presença de outros grupos de imigrantes que foram importantes para a construção da vida política e econômica de Nova Friburgo e, mais especificamente, da região das “Terras Frias”. Voltando-se novamente para o Censo de 1872, é possível identificar a presença de agentes sociais de outras províncias, situação demonstrada no quadro a seguir (Quadro 1).

\footnotetext{
${ }^{22}$ Disponível em: http://200.222.27.136/index.php/mapa-da-provincia-do-rio-de-janeiro. Data de acesso: $29 / 12 / 2020$

${ }^{23} \mathrm{~A}$ fazenda São Lourenço, que ao contrário das suas outras propriedades, não continha plantações de café. Apesar de ter 2.000 alqueires de terra, havia ali, apenas, 41 escravos e 867 animais, sendo a propriedade menor avaliada pelos inventariantes do Barão, mas terceira na quantidade de criações. MARRETTO, 0 opulento capitalista...op. cit. p. 168-180.
} 
Quadro 1: Origem da População Brasileira em Nova Friburgo/RJ -1872.

\begin{tabular}{|c|c|c|c|c|c|c|}
\hline Freguesia & RJ & MG & BA & SP & PE & P. Total \\
\hline S. J. Ribeirão & 6.416 & 119 & 44 & 180 & 10 & 6.914 \\
\hline S.J. Batista & 4.764 & 127 & 81 & 108 & 84 & 5.222 \\
\hline N.S.C. Paq. & 2.853 & 58 & 229 & 16 & 61 & 3.341 \\
\hline Sebastiana & 2.065 & 19 & 5 & 0 & 0 & 2.091 \\
\hline
\end{tabular}

Produzido pelo autor a partir do Censo de $1872 .{ }^{24}$

Os dados acima demonstram o quantitativo de mineiros presentes na Vila de Nova Friburgo, na década de setenta do século XIX. Nota-se que, nas quatro freguesias que compunham a antiga colônia suíça, havia, ao menos, mais de uma dezena de mineiros. 0 quadro ratifica a posição da recente historiografia dedicada à análise da cidade serrana, na qual se tem demonstrado a importância de grupos luso-brasileiros na construção da Vila e das regiões vizinhas. ${ }^{25}$ Ferreira ressalta o fato de Friburgo ter recebido imigrantes de origem mineira interessados nas oportunidades que as terras da Vila ofereciam por estarem situadas em uma rota de passagem do escoamento do café de Cantagalo, município vizinho, para o Rio de Janeiro. Ainda segundo a autora, alguns desses mineiros, como os Neves, de São João Del Rey, uniram-se a famílias locais, constituindo-se enquanto grandes proprietários. ${ }^{26}$

Pelo quadro, verifica-se que a maioria da população do município está na Freguesia de São José do Ribeirão, onde se concentra grande parte da produção de café, suplantando os números da própria sede da Vila. Tendo em vista a importância econômica da rubiácea, não é de se estranhar que a área tenha atraído um grande número de pessoas ao longo do século XIX. As unidades agrícolas estabelecidas precisaram de mão de obra livre e, principalmente, escrava, fazendo com que o contingente populacional aumentasse. Modificando um pouco a escala de análise, concentrando-se sobre as freguesias cujo territórios fariam parte das "Terras Frias", vê-se que os imigrantes de Minas Gerais, ocupavam, ao menos, a quarta colocação no que se refere à origem da população. Ainda que o mesmo raciocínio possa ser empregado em grande parte de Paquequer, onde “o ouro negro" também se desenvolveu, ele

\footnotetext{
${ }^{24}$ Destacaram-se, em negrito, as freguesias que compunham as “Terras Frias”.

${ }^{25}$ LISBOA, Edson Castro. Café e escravidão em Nova Friburgo no século XIX. In: MAYER e ARAÚJO (Orgs.). op. cit., p. 81-105. MARRETO, Rodrigo Marins. "Insurgência Escrava na Vila de Nova Friburgo (1820-1850)". In ARAÚJO; LO BIANCO; COSTA (Org.) Teia Serrana II... op. cit., p. 43.
}

${ }^{26}$ FERREIRA, op. cit., p. 77-80. 
não valeria para as partes de clima mais frio. Entende-se, assim, aquela região como uma área de fronteira, não um vazio, mas como uma terra de encontros, onde a população da província vizinha também optou por se aventurar. ${ }^{27}$ A produção agrícola local, ainda que menos propícia aos cafeeiros, poderia oferecer várias opções de negócios rentáveis, algo que pode ser identificado por meio da análise de uma outra documentação.

Em fevereiro de 1883, o Governo do Rio de Janeiro pediu informações sobre o estado da agricultura, da indústria pastoril e da apicultura existentes na Vila de Nova Friburgo. ${ }^{28}$ Diante do pedido, a Câmara indicou alguns nomes que seriam responsáveis pela construção de um relatório dessas atividades em cada uma das três freguesias do município. ${ }^{29}$ Haja vista Paquequer, naquela data, já não pertencer mais a Friburgo, foram encontradas, nos arquivos do fundo municipal, informações de duas unidades que formavam a região das "Terras Frias": São João Batista (Vila) e Sebastiana. ${ }^{30}$ Se o ofício produzido pelo Coronel Galiano Emílio das Neves apresentou dados bem genéricos sobre a primeira freguesia, ${ }^{31}$ o que foi elaborado por Alfredo Augusto de Freitas descreveu com maiores detalhes o cenário agrícola da segunda porção territorial. ${ }^{32}$ De acordo com o documento, plantavam-se essencialmente cere-

\footnotetext{
${ }^{27}$ Sobre essa perspectiva de "fronteira", ver: MACHADO, Marina Monteiro. Entre fronteiras: posses e terras indígenas nos sertões (Rio de Janeiro, 1790-1824). Guarapuava, RJ: Unicentro, 2012.

${ }^{28}$ Portaria do Governo pedindo informação sobre o estado geral da agricultura e da indústria pastoril. Doc. № 4935. Fundação D. João VI. Disponível no site: https://www.djoaovi.com/arquivo/promemoriadigital/ fundoadmnf. Acesso em: 1 dezembro de 2020.

${ }^{29}$ Idem, p. 2

${ }^{30}$ Em 1881, após um imbróglio na Câmara Provincial, a Freguesia de Nossa Senhora da Conceição do Paquequer foi desmembrada de Nova Friburgo, passando a pertencer ao Município do Carmo. LIMA, Daniel Leite. Carmo no Século XIX: o arraial, a vila, e a cidade oitocentista de Nossa Senhora do Monte do Carmo. Gráfica e Editora Ried LTDA. 2º Edição: Rio de Janeiro: 2020, p. 467-478.

${ }^{31} \mathrm{O}$ autor se resume a informar que os principais gêneros de cultura do município são: o café, o milho, o feião, o arroz, a batata e a mandioca; afirma ainda que a indústria pastoril é empregada em pequena escala. Ofício do Coronel Galiano Emilio das Neves informando sobre a agricultura, indústria pastoril, etc. Doc. №5000. Fundação D. João VI. Disponível no site: https://www. djoaovi.com/arquivo/promemoriadigital/fundoadmnf. Acesso em: 1 dezembro de 2020. O fato de Galiano das Neves ter sido responsável pelo ofício referente à Freguesia da Vila é mais um elemento que comprova a postura metodológica de não limitar a região analisada somente a Sebastiana. O coronel, apesar de ter residência na área central, possuía, ao menos, uma propriedade rural no final dos limites daquele território, ou seja, vizinho da outra porção. Se o fato de ele citar o café como um dos cultivares demonstra que havia regiões propícias à rubiácea, a menção a outros produtos, como a batata, milho e feijão, permite a percepção de que algumas áreas ligadas administrativamente à sede possuíam características semelhantes as descritas no atual Distrito de Teresópolis.

${ }^{32}$ Ofício de Alfredo Augusto de Freitas Pereira informando sobre a agricultura, indústria pastoril, etc. Arquivo do Fundo da Administração de Nova Friburgo. Doc. № 4989. Fundação D. João VI. Disponível no site: https://www.djoaovi.com/arquivo/promemoriadigital/fundoadmnf. Acesso em: 1 dezembro de 2020. Segundo as informações presentes no Almanaque Laemmert, ele era proprietário e inspetor da
} 
ais, como: milho, feijão e arroz. Também eram cultivadas a mandioca e, em menor escala, a uva, com a qual já se fazia algum vinho, que ainda carecia de melhoramentos. Outro dado importante se refere à produção de batatas, "principal fonte da antiga riqueza desta freguesia", que, após ser atacada por uma moléstia, (praga), destinou-se praticamente ao consumo interno. Já a cana não conseguia se desenvolver por conta do clima frio e do "grande inconveniente das geadas". ${ }^{33}$

No tocante à indústria pastoril, o relato aponta que "quatro em cinco lavradores" se dedicavam à criação de gado bovino, que era de qualidade "magnífica, muito leiteiro e optimo par ao corte". ${ }^{34}$ Chama atenção o fato de o autor, apesar de mencionar que muitos lavradores se dedicavam a esse tipo de atividade, afirmar que a criação era bem "diminuta". Ao que parece, ele deixa transparecer a sua opinião de que o gado teria um bom potencial para se expandir naquelas terras. Tal possibilidade ainda fica mais clara quando ele faz menção a fazenda de um lavrador, Ignácio da Veiga Barbuda, fabricante de queijos que "rivaliza[va]m com os bons queijos mineiros". ${ }^{35}$ Naquele território, também se criavam suínos, caprinos e ovinos. Os dois últimos eram destinados ao consumo local, e os porcos para "exportação", já que, principalmente, o toucinho era vendido para Magé. Ainda, relata-se a presença de uma indústria apícola que, na sua quase totalidade, está nas mãos de pequenos lavradores, em grande parte originários das Ilhas dos Açores. Segundo o relato, eles conseguiam extrair dos seus cortiços uma grande quantidade de cera e de mel que já eram exportados, inclusive para a Corte. Por fim, o maior problema apontado para o melhor desenvolvimento da produção agropecuária é a "queixa geral em todo o Império", ou seja, a "grande falta de braços", que fazia com que se pagassem salários "caríssimos" aos poucos jornaleiros disponíveis para o serviço. ${ }^{36}$

As informações contidas no relatório não somente ratificam as afirmações feitas nos trabalhos anteriores, como trazem avanços para o entendimento da região. Evidencia-se, mais uma vez, o papel da plantação de gêneros

\footnotetext{
Instrução Pública de Sebastiana. Ver Almanak Laemmert, edição do ano de 1883. Disponível no site: http:// objdigital.bn.br/acervo_digital/div_periodicos/almanak/almanak.htm. Acesso em: 1 novembro de 2020. ${ }^{33}$ Ofício de Alfredo Augusto de Freitas Pereira informando sobre a agricultura, indústria pastoril, etc. Arquivo do Fundo da Administração de Nova Friburgo. Doc. № 4989. Fundação D. João VI. Disponível no site: https://www.djoaovi.com/arquivo/promemoriadigital/fundoadmnf. Acesso em: 1 dezembro de 2020.

${ }^{34}$ Idem.

${ }^{35}$ Idem.

${ }^{36} \mathrm{Idem}$.
} 
para o consumo e abastecimento de um mercado interno, como no caso do milho, que é essencial inclusive para a criação de animais. Esse é outro elemento destacado como potencial da localidade. É possível que a criação não fosse a principal atividade dos lavradores, o que explica o pequeno número de agentes que se definiam, no Almanaque Laemmert, como criadores ou possuidores de fazendas criar, porém ela estava presente em grande parte das propriedades (em quatro de cinco!). O próprio Dimas Ferreira Pedrosa foi um dos poucos que possuiu e se declarou proprietário de uma fazenda de criar, situada na Freguesia da Vila. Destaca-se, também, a posição da região como exportadora de gêneros para mercados regionais vizinhos, como Magé, e até para a Corte. A carne suína, a cera e o mel deveriam ser atividades lucrativas e que necessitavam de tropas de mula e de estradas para serem transportadas. Contudo, esses gêneros não foram os únicos exportados daquela região. Ao que parece, as batatas foram, durante muitos anos, a principal fonte de riqueza da população local. Uma rápida apreciação do número de produtores de batatas listados no jornal nos anos anteriores comprova a importância da produção do tubérculo, que, também, fez parte das atividades econômicas de Pedrosa. A moléstia destacada por Augusto de Freitas estaria relacionada à desaparição desses produtores, que não figuraram na listagem da Freguesia de Sebastiana. ${ }^{37}$

Já a reclamação sobre a mão de obra está inserida no debate nacional sobre as consequências do final da escravidão. O número de escravizados presentes nas freguesias que compunham as "Terras Frias" é menor do que em outras áreas, como as destinadas à produção do café (Freguesia de São José do Ribeirão). ${ }^{38}$ É bem provável que a natureza das atividades realizadas fizesse com que os produtores utilizassem uma escravaria menor, recorrendo, inclusive, a imigrantes portugueses. Este grupo, por sua vez, pode ter vindo de outras áreas vizinhas destinadas ao cultivo da rubiácea. Ele fixou-se nesse novo território e seus membros se tornaram, com o tempo, proprietários locais. ${ }^{39}$ Tal tema certamente carece de estudos mais aprofundados com base em análises mais específicas, que ultrapassem os dados apresentados pelo Censo de 1872. Por ora, percebe-se que a escravidão esteve disseminada na região

\footnotetext{
${ }^{37}$ Entre os anos de 1857 e 1864, foram listados, na Freguesia da Vila, 17 agentes dedicados ao cultivo da batata. Dimas Ferreira Pedrosa esteve na lista nos anos de 1858 e 1859. Contudo, depois desse período, seja na Vila, seja em Sebastiana, essa atividade não foi mencionada. Ver Almanak Laemmert. Disponível no site: http://objdigital.bn.br/acervo_digital/div_periodicos/almanak/almanak.htm. Acesso em: 1 novembro de 2020.
}

${ }^{38}$ LISBOA, op. cit.; MARRETO, O opulento... op. cit.

${ }^{39}$ FRAZÃO, Um negociante... op. cit. 
estudada, já que se sabe que alguns proprietários locais, inclusive portugueses (como o Barão de Nova Friburgo) e mineiros (como Dimas Ferreira Pedrosa), possuíam escravizados. ${ }^{40}$

Diante de tudo isso, parece não faltar motivos para que pessoas de outras localidades viessem para aquela região. Entende-se, assim, que o papel desses migrantes só poderá ser melhor dimensionado diante de análise qualitativas, que tratem da biografia de alguns desses homens e mulheres que chegaram ao território friburguense nas primeiras décadas do século XIX. Dimas Ferreira Pedrosa, a estrela de primeira grandeza deste texto, está inserido em tal contexto migratório. Dessa forma, e também tendo em vista tal questão, atentar-se-á, agora, para trajetória política, econômica, e social de Pedrosa: latifundiário, presidente da Câmara e membro de uma nobreza agrária local.

\section{O político Dimas Ferreira Pedrosa: uma breve explanação}

Dimas Ferreira Pedrosa (1817-1882) nasceu na província de Minas Gerais. ${ }^{41}$ Acredita-se que ele descenda da família Ferreira Pedrosa, de origem portuguesa, mas já presente em território mineiro desde meados do século XVIII. Ele era filho de José Tomás Pedrosa e Angélica da Silva, casados em Cachoeira do Campo, em 1815. Dimas foi batizado naquela província, em 1819, ou seja, provavelmente aos 2 anos de idade. Seu pai já estaria morto em 1828 . Em 1831, sua mãe, com 39 anos e viúva, foi qualificada no censo como "fiadeira" e ele, aos 14 anos de idade, como jornaleiro..$^{42}$ Não se sabe precisamente o momento e os motivos que o trouxeram ao território fluminense, mas, diante do que foi exposto, ele deve ter vindo em busca das oportunidades econômicas ali oferecidas. Em 1843, Pedrosa aparece na listagem da Guarda Nacional da Freguesia de Nossa Senhora da Conceição do Paquequer. Ainda segundo o documento, aos 26 anos, o guarda era solteiro e negociante. ${ }^{43}$ Casou-se com Querubina Candida Pedrosa, tendo dois filhos: Maria da Gloria Pedrosa e Dimas

\footnotetext{
${ }^{40}$ MARRETO, Rodrigo Marins, O opulento... op. cit.

${ }^{41}$ Livro de Registro de Óbitos da Freguesia de São João Batista de Nova Friburgo, nº3 folha 200. Paróquia de São João Batista Nova Friburgo.

${ }^{42}$ ISOLDI, Maria Celma Exner Godoy e FILHO, Carlos Alberto da Silveira Isoldi. Algumas famílias povoadoras do Alto do Rio das Velhas: Ferreira Pedrosa, Aguiar, Pereira Lima e Rodrigues Peixoto. Revista da ASBRAP, n..26, 2019, p. 291. Disponível em: www.asbrap.or.br/documentos/revistas/rev_26_2019/k-algumas_familias_povoadoras_do_alto_rio_das_velhas_isoli.pdf Data de acesso 24/02/2020.

${ }^{43}$ Lista do Conselho de qualificação da Guarda Nacional. Doc 2575. Fundação D. João VI/Nova Friburgo.
} 
Ferreira Pedrosa. ${ }^{44}$ Este, nascido em 25 de setembro de 1866 e batizado dois anos mais tarde na Freguesia de São João Batista, sede da Vila de Nova Friburgo, por Guilherme Salusse, vereador (1865 e 1868) e membro de importante família local..$^{45}$ Já sobre a filha, sabe-se apenas que ela foi casada com Luis Machado Coelho, que, mais tarde, foi sócio do sogro em um dos seus empreendimentos.

O mineiro teve uma carreira política de destaque em Nova Friburgo. ${ }^{46}$ Após ter exercido a função de fiscal na Freguesia do Paquequer (1847-1851), o membro do partido liberal foi vereador em mais três pleitos, ocupando o posto de Presidente da Câmara Municipal por oito anos (1856-1864). ${ }^{47}$ À frente da vereança, defendeu a construção de estradas que melhorariam a comunicação de áreas produtoras de gêneros agropecuários com a sede da Vila e/ou com outras porções do território fluminense. ${ }^{48}$ Por meio dessa estratégia, ${ }^{49}$ ele conseguiu auferir capital político que o fez se manter no cargo, consolidando-se, assim, como membro da administração e, por conseguinte, da "boa sociedade imperial". ${ }^{50}$ Durante alguns anos, Dimas Pedrosa soube aliar bem a defesa dos caminhos - preocupação coletiva - aos seus interesses econômicos particu${ }^{44}$ Inventário de Dimas Ferreira Pedrosa. Tribunal de Justiça do Rio de Janeiro (TJ-RJ). Acervo Permanente,
caixa: 01.411.138-0.
${ }^{45}$ Livro de Registro de Batismo da Freguesia de São João Batista de Nova Friburgo, n.ำ 3, folha 153. Paróquia
de São João Batista Nova Friburgo. Guilherme, descendente de Guillaume Marius Salusse e Marianne Salusse
Joset, foi latifundiário e proprietário de açougue na Vila de Nova Friburgo. Seus pais eram donos de um
importante hotel, localizado no centro do município. SAMPAIO, Sérgio Bittencourt. O Hotel Salusse em Nova
Friburgo. Núcleo familiar, político e social. Rio de Janeiro: Imprimatur, 2009, p. 54.

${ }^{46}$ Para uma análise mais aprofundada da vida política de Pedrosa, ver FRAZÃO, Caminhos e descaminhos... op. cit.

${ }^{47}$ Encontrou-se seu nome na lista dos eleitores do partido liberal em 1863 e 1869. Correio Mercantil. Edição de 15 de agosto de 1863; Jornal do Comércio. Edição de 13 de abril de 1869. Ambos disponíveis no site da Hemeroteca Digital. Disponível em: https://bndigital.bn.gov.br/hemeroteca-digital/ . Acesso em 20 de dezembro de 2020.

${ }^{48}$ Anos antes, outro presidente da Câmara Municipal, Jean Bazet, possuiu interesse nas estradas municipais, já que muitas delas ligavam regiões produtoras de café a centros consumidores. MARRETO, Rodrigo Marins e FRAZÃO, Gabriel Almeida. "“Em benefício da elegância e a salubridade pública”: Jean Bazet e a boa sociedade imperial na vila de Nova Friburgo (1828-1852)." In. COSTA, e GUIMARÃES (Orgs), Memórias do... op. cit., p. 57-74.

${ }^{49}$ Aqui, entende-se estratégia como a capacidade de previsão e de antecipação de um agente social do entendimento do tempo e do espaço, ou seja, o que permite a um sujeito capitalizar vantagens e preparar futuras expansões, tentando conquistar certa independência em relação a circunstâncias futuras. Ou, dito em outras palavras, é a forma como o bom jogador consegue, ciente das regras do jogo, adaptar-se e inventar-se diante das situações que se apresentam. Sobre o conceito ver: CERTEAU, Michel. A invenção do cotidiano. Vol. 1: Artes de fazer. Petrópolis, RJ: Vozes, 2008, p.99-100; PEDROZA, Manuela. Engenhocas da Moral: redes de parentela, transmissão de terras e direitos de propriedade na freguesia de Campo Grande (Rio de Janeiro, século XIX). Rio de Janeiro: Arquivo Nacional, 2011, p.26

${ }^{50}$ MATTOS, Ilmar Rohloff. O Tempo Saquarema: a formação do Estado Imperial. Rio de Janeiro: Acess, 1999; MATTOS, Ilmar Rohloff e GONÇALVES, Márcia de Almeida. O Império da Boa Sociedade: a consolidação do Estado Imperial Brasileiro. São Paulo: Atual, 1991. 
lares, conseguindo: apoio de vereadores para arrematação de obras locais; defesa da administração municipal sobre sua atuação nos trechos arrematados junto ao governo provincial; e auxílio na construção de vias próximas e/ou pertencentes às suas propriedades, favorecendo seus negócios.

Contudo, a partir do segundo mandato, uma série de imbróglios minaram pouco a pouco seu prestígio político. Após ser acusado, por outros camarários, de estar em posse do dinheiro do cofre da Câmara e de não ter apresentado documentos que comprovassem os gastos de sua administração, chegou a ser alvo de um processo criminal para cobrança de valores dispendidos sem a devida justificativa. Pedrosa ainda se elegeu vereador mais uma vez, ocupando a vereança por três anos (1865-1867), porém não mais exerceu a presidência. A falta de apoio naquele momento fez com que fosse demovido do cargo, por desrespeito aos colegas, sendo enquadrado no artigo $32 \mathrm{da}$ lei de 1828 que regulamentava o funcionamento das câmaras municipais. ${ }^{51}$ Desde então, até a sua morte, figurou, apenas, como suplente nas eleições para administração municipal. ${ }^{52}$

Dimas Ferreira Pedrosa e dois companheiros de viagem foram assassinados a tiros e facadas, em 1882, quando voltavam da Freguesia de Nossa Senhora da Conceição do Paquequer (Sumidouro). Segundo os jornais da épo$\mathrm{ca}$, o crime foi motivado por várias questões forenses com as quais Pedrosa estava envolvido. Entende-se que a gravidade do ato, bem como a importância política da vítima, fez com que o caso fosse noticiado em jornais de circulação regional. ${ }^{53}$ Se as estradas e os imbróglios fizeram parte da vida política desse sujeito, cabe entender melhor a sua atuação econômica em Nova Friburgo e, principalmente, na região das “Terras Frias”.

\section{Negociante-fazendeiro: atuação econômica do mineiro em Friburgo}

Apesar de já estar em Nova Friburgo desde 1843 na qualidade de negociante, só foram encontrados registros das atividades econômicas de Dimas Ferreira Pedrosa a partir de 1853. Com base em uma pesquisa onomástica realizada no Almanak Laemmert, traçou-se a sua trajetória econômica na

\footnotetext{
${ }^{51}$ BRASIL. Lei de Outubro de 1828. http://www.planalto.gov.br/ccivil_03/leis/lim/LIM-1-10-1828.htm. Acesso em: 01/12/2020.

${ }^{52}$ FRAZÃO, Caminhos e descaminhos...op. cit.

${ }^{53}$ Gazeta de Notícias, terça-feira de 19 de dezembro de 1882; Jornal do Comércio de 1 de dezembro de 1883 ; O Monitor Campista, 21 de dezembro de 1882.Hemeroteca Digital. Disponível em: https://bndigital.bn.gov. br/hemeroteca-digital/. Acesso em 20 de dezembro de 2020.
} 
província Fluminense (Quadro 1). o procedimento é importante não somente para o acompanhamento de suas ações, mas também para a visualização do modo como ele se definiu ao longo da vida.

Quadro 1: Atividades econômicas de Dimas F. Pedrosa (1854-1882)

\begin{tabular}{|c|c|c|}
\hline Ano & Freguesia & Atividades econômicas \\
\hline $1853-1857$ & Carmo & Casa de Pasto \\
\hline $1854-1857$ & Paquequer & Fazendeiro sem engenho de pilões \\
\hline $1858-1859$ & Vila & Fazendeiro de criar e de batatas \\
\hline $1860-1864$ & Vila & Fazendeiro de criar \\
\hline 1865 & Vila & Negociante \\
\hline $1875-1876$ & Vila & Proprietário do Hotel Cantagalo \\
\hline $1877-1879$ & Vila & $\begin{array}{c}\text { Proprietário do Hotel Cantagalo; de bilhar; de } \\
\text { armazém de receber gêneros em consignação. }\end{array}$ \\
\hline 1880 & Vila & $\begin{array}{c}\text { Proprietário do Hotel Cantagalo; de bilhar, de } \\
\text { armazém de receber gêneros em consignação; } \\
\text { cocheira de alugar animais e negociante. }\end{array}$ \\
\hline 1882 & Vila & \begin{tabular}{c} 
Proprietário do Hotel Cantagalo e negociante. \\
\hline
\end{tabular}
\end{tabular}

Fonte: Produzido pelo autor a partir do Almanak Laemmert..$^{54}$

Nota-se que, antes de figurar no território friburguense, ele aparece como proprietário de um estabelecimento comercial na Freguesia do Carmo, pertencente ao município de Cantagalo. Ao estar à frente de uma "casa de pasto", definindo-se como negociante, ele confirma o fato de a região ser uma zona de circulação de pessoas e de produtos, ratificando importância econômica do tropeirismo, que se destacou ainda mais após a vinda da Corte..$^{55} \mathrm{O}$ trânsito de animais por estradas que ligam o território a Minas, a Cantagalo, a Friburgo, a Magé e à capital fluminense, além da necessidade de lugares para descanso dos animais, ${ }^{56}$ deveria trazer grande rentabilidade ao negócio.

\footnotetext{
${ }^{54}$ Almanak Administrativo, Mercantil e Industrial da Corte do Rio de Janeiro. Foram consultadas as informações referentes ao município de Nova Friburgo de 1840 a 1888. Disponíveis no site: http://www-apps. crl.edu/brazil/almanak.

${ }^{55} \mathrm{~A}$ importância dos tropeiros para o escoamento de mercadorias já foi destacada, nos anos 60 , por Maria Sylvia de Carvalho Franco e, nas décadas seguintes, por Alcir Lenharo. Ver, respectivamente: FRANCO, Maria Sylvia de Carvalho. Homens livres na ordem escravocrata. São Paulo: UNESP,1997; LENHARO, Alcir. As Tropas da Moderação. 0 Abastecimento da Corte na Formação Política do Brasil - 1808-1842. Rio de Janeiro: Prefeitura da Cidade do Rio de Janeiro, 1992.

${ }^{56} \mathrm{Como}$ a autonomia de mulas carregadas era de cerca de 4 léguas (aproximadamente $26 \mathrm{~km}$ ), os animais precisavam de lugares para descanso. Sobre o papel dos tropeiros em Carmo e região, ver: LIMA, op. cit., p. 65-129.
} 
O fato é que, três anos mais tarde, ele já figura como "fazendeiro" em Nova Friburgo, primeiramente em Paquequer, e, em 1858, na Freguesia da Vila, já associado à criação de animais e ao plantio de batatas. Tendo em vista seu negócio anterior, é provável que Pedrosa tivesse muares para transporte de mercadorias. Lenharo chamou a atenção para o fato de muitos tropeiros terem sido proprietários de terras, conjugando muitas vezes a produção de gêneros para venda com a criação/ e ou comércio de animais. Embora o autor discorde da visão de que os condutores de tropa seriam apenas homens livres e pobres subordinados a proprietários rurais, ele reconhece certa tendência, por parte daqueles que exerciam a atividade, de apagar tal traço da sua biografia, já que ela poderia atrapalhar a sua ascensão social.$^{57}$ Então, se o mineiro chegou a conduzir mulas, esse negócio não foi descrito por ele, que poderia ter como estratégia ascender socialmente.

O fato é que Dimas Ferreira Pedrosa se definiu somente como fazendeiro nos anos em que esteve à frente da presidência da Câmara (1858-1864). A partir de então, ele voltou a se denominar como negociante. Entretanto, isso não significa que ele tenha deixado de ser latifundiário e se desligado do negócio de animais. Apreciando seu inventário, percebe-se que $55 \%$ do seu patrimônio estaria empregado em terras, animais e plantações (Quadro 2).

Quadro 2: Bens de Dimas Ferreira Pedrosa (1883)

\begin{tabular}{|c|c|c|c|}
\hline Itens & Valor (Réis) & Valor Libras & \% Bens \\
\hline Terras & $33: 350 \$ 000$ & 2.967 & 51 \\
\hline Construções & $16.282 \$ 000$ & 1.448 & 25 \\
\hline Escravos & $7.100 \$ 000$ & 632 & 11 \\
\hline Mobília e ferramentas & $4: 094 \$ 100$ & 364 & 6 \\
\hline Animais & $2: 243 \$ 000$ & 200 & 3 \\
\hline Gêneros & $1: 000 \$ 000$ & 89 & 2 \\
\hline Plantações & $9.00 \$ 000$ & 80 & 1 \\
\hline Total & $\mathbf{6 4 : 9 6 9 \$ 1 0 0}$ & $\mathbf{5 7 8 0}$ & $\mathbf{1 0 0}$ \\
\hline Dívidas & $\mathbf{2 3 : 6 5 9 \$ \mathbf { 1 4 0 }}$ & $\mathbf{2 . 1 0 5}$ & $\mathbf{3 6}$ \\
\hline
\end{tabular}

Fonte: Elaborado pelo autor com base no Inventário de Dimas Ferreira Pedrosa. ${ }^{58}$

Um olhar mais minucioso sobre os dados revela um número ainda maior. O negociante, ao final da vida, possuía 50:605\$400 réis alocados em imóveis rurais, o que representaria 78\% do seu patrimônio (Quadro 3)

\footnotetext{
${ }^{57}$ LENHARO, op. cit., p. 92-95.

${ }^{58}$ Inventário de Dimas Ferreira Pedrosa. Tribunal de Justiça do Rio de Janeiro (TJ-RJ). Acervo Permanente,
} 
Quadro 3: Bens por propriedades de Dimas Ferreira Pedrosa (1883)

\begin{tabular}{|c|c|c|c|}
\hline Itens & Valor $($ Reis) & Valor Libras & \% Bens \\
\hline Fazenda Rio Grande & $43: 355 \$ 400$ & 3.857 & 67 \\
\hline Casa de Vivenda (Vila) & $12: 111 \$ 700$ & 1.078 & 19 \\
\hline Sítio Retiro & $7: 250 \$ 000$ & 645 & 11 \\
\hline Hotel Cantagalo (Mobília) & $2: 252 \$ 000$ & 200 & 3 \\
\hline Total & $\mathbf{6 4 : 9 6 9 \mathbf { 1 0 0 }}$ & $\mathbf{5 0 8 0}$ & $\mathbf{1 0 0}$ \\
\hline
\end{tabular}

Fonte: Elaborado pelo autor com base no Inventário de Dimas Ferreira Pedrosa.

Essas propriedades, que somavam 361 alqueires, situavam-se nas “Terras Frias" e se enquadram no perfil regional descrito. Tomando como base a Fazenda Rio Grande, descrita com maiores detalhes no inventário, vê-se que os seus 291 alqueires eram destinados à criação de 84 animais (30 porcos) e ao plantio de milho, contando, apenas, com 3 escravos. Além da criação, o mineiro possuía uma pequena casa de negócio, cujos bens somavam 1:000\$000 de réis, que deveria servir para atender a demanda da população local. Ele pareceu, assim, naquela propriedade, conjugar a atividade de produção agrícola com a de negociante, ainda que esta, pelo valor dos gêneros ali encontrados, não envolvesse grandes montantes.

Tomando como referência o trabalho de João Fragoso, que, baseando-se no Almanack Laemmert, estabeleceu uma classificação para os proprietários locais em terras fluminenses, Dimas Ferreira Pedrosa pode ser percebido como um negociante-fazendeiro, ou seja, grupo que teve sua fortuna agrícola originária no comércio. ${ }^{59}$ Para o autor, esses agentes, não oriundos de uma elite agrária, buscavam uma ascensão social em suas ações no mercado fundiário. Outra característica do grupo está relacionada aos valores dispendidos nas transações comerciais, geralmente inferiores a 1.000 libras esterlinas, o que os diferenciava dos fazendeiros capitalistas (elite) e dos simples negociantes. ${ }^{60} \mathrm{O}$

caixa: 01.411.138-0. A conversão para libra esterlina é uma metodologia utilizada pela historiografia para que possa estabelecer comparações entre valores em temporalidades distintas, já que o valor da moeda brasileira variava muito ao longo do tempo. Para a conversão, utilizaram-se as informações disponibilizadas em: FILHO, Heitor Plínio de Moura. Câmbio de longo prazo do mil-réis: uma abordagem empírica referente às taxas contra a libra esterlina e o dólar (1795-1913). Cadernos de História, Belo Horizonte, v. 11, n. 15, jul.-dez. 2010, p. 9-34. Disponível em: http://periodicos.pucminas.br/index.php/cadernoshistoria/ article/view/P.2237-8871.2010v11n15p9. Acesso em: 20 dezembro de 2020.

${ }^{59}$ FRAGOSO, João. Os barões do café e o sistema agrário escravista: Paraíba do Sul/Rio de Janeiro (1830-1888). Rio de Janeiro: 7 Letras, 2013, p.124-144.

${ }^{60}$ Os primeiros eram os membros do subgrupo mais rico - com menos de 1.000 hectares de terras - e que se utilizavam do mercado apenas para consolidar a sua posição como membros da aristocracia fundiária. 
exame da movimentação cartorial de Pedrosa, no único cartório da Vila de Nova Friburgo no século XIX, confirma essa percepção.

Quadro 4: Resumo das transações de imóveis de Dimas Ferreira Pedrosa (1857-1880)

\begin{tabular}{|c|c|c|c|c|c|c|c|c|}
\hline \multirow{2}{*}{ Ano } & \multicolumn{2}{|c|}{ Compras } & \multicolumn{2}{c|}{ Vendas } & \multicolumn{2}{c|}{ Troca } & \multicolumn{2}{c|}{ Saldo } \\
\cline { 2 - 9 } & Reis & Libras & Reis & Libras & Reis & Libras & Reis & Libra \\
\hline 1857 & $29: 400 \$ 000$ & 3.314 & $30: 000 \$ 000$ & 3.382 & 0 & 0 & $600 \$ 000$ & 65 \\
\hline 1858 & $3: 800 \$ 000$ & 0 & 0 & 0 & 0 & 0 & $-3: 800 \$ 000$ & -412 \\
\hline 1860 & $10: 000 \$ 000$ & 1.059 & $2: 000 \$ 000$ & 212 & 0 & 0 & $-8: 000 \$ 000$ & -847 \\
\hline 1861 & $10: 000 \$ 000$ & 1.069 & $15: 000 \$ 000$ & 1.604 & 0 & 0 & $5: 000 \$ 000$ & 534 \\
\hline 1873 & $5: 600 \$ 000$ & 584 & $600 \$ 000$ & 63 & 0 & 0 & $-5: 000 \$ 000$ & -521 \\
\hline 1879 & 0 & 0 & $1: 000 \$ 000$ & 92 & 0 & 0 & $1: 000 \$ 000$ & 92 \\
\hline 1880 & $3: 000 \$ 000$ & 273 & 0 & 0 & $6: 500 \$ 000$ & 592 & $3: 500 \$ 000$ & 318 \\
\hline Total & $\mathbf{6 1 : 8 0 0 \$ 0 0 0}$ & $\mathbf{6 . 7 1 3}$ & $\mathbf{4 8 : 6 0 0} \$ \mathbf{0 0 0}$ & 5.353 & $\mathbf{6 : 5 0 0} \$ 000$ & 592 & $-6: 700 \$ 000$ & -767 \\
\hline
\end{tabular}

Fonte: Elaborado pelo autor com base nos livros de Notas do Cartório $2^{\circ} 0$ fício (NF). ${ }^{61}$

Logo de início, vê-se que algumas das movimentações anuais superam a quantia de 1.000 libras esterlinas. Contudo, salienta-se que, na maioria dos anos, o saldo foi negativo, demonstrando que o proprietário dispendeu mais dinheiro nas aquisições fundiárias do que obteve com a venda de terras e/ ou com a venda de pés de café. Ou seja, ao que parece, ele não tinha como objetivo conseguir capital com a venda de bens rurais por meio de algum tipo de especulação. A única exceção encontrada esteve no ano de 1857, quando ele revendeu um direito de herança, adquirido meses antes por 20:000\$000, pela quantia de 22:000\$000 réis. Em síntese, foi utilizado dinheiro de outra atividade, possivelmente a de negociante, para a compra de fazendas.

Nesse sentido, salienta-se que Dimas Ferreira Pedrosa também esteve envolvido com o mundo da escravidão. Ao final de sua vida, ele possuía 4 escravos, ou seja, além dos citados anteriormente, mais 1 localizado em sua residência na Vila, o que somava $11 \%$ do seu patrimônio. Contudo, somente esse dado parece não dar conta da importância da escravidão nos seus negócios.

Os segundos, sempre listados no Almanak como comerciantes e/ou negociantes, eram os principais abastecedores de mercadorias e de créditos para os pequenos e mais pobres produtores. Por isso, esse grupo possuía grande capilaridade social, atingindo um grande número de agentes, mas com quantias, em $90 \%$ dos casos, menores do que 500 libras. Ibidem.

${ }^{61}$ Foram examinados os Livros de Notas do Cartório do 2º Ofício de Nova Friburgo, de 1840 a 1888. 
Por meio da análise da documentação cartorial de Nova Friburgo, percebeu-se que ele se envolveu diretamente em várias transações de escravizados. De 1861 a 1881, foram 5 operações de venda, que, ao todo, envolveram 13 cativos e somaram a cifra de 24:532\$500 réis (2.267 libras); a maior delas foi em 1881 , quando recebeu 12:000\$000 (1.527 libras) por 6 deles. No que se refere às compras, de 1871 a 1881, por 7 vezes, ele apareceu nos livros: em número totais, adquiriu 11 escravos, por 16:600\$000 réis. 0 maior investimento feito neste tipo de operação foi em 1871, quando, por 6:000\$000 réis, tornou-se proprietário de 4 trabalhadores de roça. 0 fato de o saldo das operações ter sido positivo, 7:932\$500 réis (730 libras), e o de a maior alienação de bens ter ocorrido na década de oitenta deveriam fazer parte de uma estratégia mais ampla, que pode ser apreciada quando se volta ao exame da movimentação das suas outras propriedades.

Extrapolando os dados do quadro 4, identifica-se um claro movimento de Dimas Ferreira Pedrosa em direção ao centro da Vila. Enquanto proprietário, saiu de Paquequer, adquirindo fazendas em áreas que pertenciam ao território a Freguesia de São João Batista. A movimentação poderia fazer parte da sua estratégia política, haja vista ter se iniciado no momento em que ele passou a fazer parte da Câmara Municipal. Além disso, nos anos finais de sua vida, ele parecia apostar nas atividades comerciais que adquiriu no centro do município. Recorrendo ao quadro 1, observa-se que, desde 1875, Pedrosa optou por listar no Almanak apenas as atividades que exercia na sede municipal. $\mathrm{O}$ ano de 1880 marcou o auge do processo, pois foi quando o imigrante obteve capital, com a troca de uma das suas fazendas, para adquirir uma propriedade na praça principal da cidade, próxima a residência do Barão de Nova Friburgo. Nesse momento, o saldo positivo das transações demonstra uma inversão: se em vários anos ele aplicou dinheiro de outras atividades em terras, agora, utilizou o dinheiro advindo de uma troca de propriedades para a compra da casa e, possivelmente, para aplicar no comércio. Não parece ser por acaso que, em 1881, ele tenha feito a sua maior venda de cativos, valor que não foi direcionado a aquisição de outras propriedades rurais. É plausível que, diante do crescimento da Vila, da inauguração da ferrovia e do grande fluxo de pessoas, ${ }^{62}$ Pedrosa tenha optado por investir em seus negócios no centro urbano, como: o bilhar; o Hotel Cantagalo; e as cocheiras de aluguel. Contudo, algo não deve ter saído como ele previa e essas vendas podiam estar ligadas à

\footnotetext{
${ }^{62} \mathrm{O}$ município passou a receber várias pessoas interessadas em tratamento de saúde. PROENÇA, Ane Thereza de Almeida. "Senhor vereador doutor: as frentes de atuação de Carlos Éboli na Câmara Municipal de Nova Friburgo.” In. COSTA e GUIMARÃES, Memórias do... op. cit., p. 95-114.
} 
falta de capital e/ou à necessidade do pagamento de dívidas. A situação econômica da família, após a morte do negociante-fazendeiro, ratifica a hipótese.

Atendo-se apenas aos números do inventário, constata-se que Pedrosa deixou uma dívida equivalente a $36 \%$ do total dos seus bens. Ele devia a negociantes de roupas e de tecidos, localizados na Corte, a grandes proprietários locais, como o Barão de Duas Barras, e meses de aluguel aos proprietários do prédio onde se localizava o hotel. Diante da falta de meios para pagar a dívida, todos os bens do imóvel, estes a pedido da família, a casa na sede da Vila e a própria Fazenda Rio Grande foram a leilão, em 1883. ${ }^{63}$ Mesmo se definindo como negociante, endividado e alienando parte do seu patrimônio rural para o desenvolvimento do comércio, ele manteve 361 alqueires de terra em suas mãos. Acredita-se que isso se deva, ao menos em parte, à defesa do padrão social conquistado por ele e que o ajudou na vida política, ou seja, a um certo ar de nobreza, muito caro aos seus descendentes.

\section{Dimas Ferreira Pedrosa, e a nobreza agrária das “Terras Frias"}

Dimas Ferreira Pedrosa poderia ser "classificado" de várias formas, a depender da perspectiva historiográfica. Levando em consideração, apenas, a posse de escravizados, ele seria um micro-proprietário, alguém que deteve de 1 a 10 cativos. $^{64}$ Tendo em vista a sua participação na política de Nova Friburgo, o imigrante mineiro poderia ser pensando como um membro da boa sociedade imperial, ou seja, alguém que, mesmo em pequena escala, envolveu-se com a administração do Império do Brasil, sendo defensor da ordem escravista.${ }^{65}$ Baseando-se na forma como o próprio agente social se definia e

\footnotetext{
${ }^{63} \mathrm{O}$ edital foi publicado e apregoado no prédio da Câmara em 01 de fevereiro de 1883. Foram feitos 9 leilões e os bens não foram arrematados. Diante disso, a viúva pediu para que o pregão fosse publicado na Corte, para que os comerciantes dali tivessem acesso. Após isso, em 24 de fevereiro, os bens avaliados em 2:552.000 foram arrematados por Manuel Augusto do Valle que ofereceu um lance de 10.000 réis acima do valor estabelecido. Os bens foram arrematados em leilão, em 18 de dezembro de 1883, por Lengruber e Cia, negociantes matriculados na Junta Comercial do Rio de Janeiro. Ainda que não se conheça por qual preço tais bens foram arrematados, sabe-se que, em 1886, eles foram adquiridos, pelo valor 13:750.000 réis, por Antonio José Mendes, negociante e proprietário de várias terras próximas àquela fazenda. Requerimento Lengruber e Cia. Doc5585_requerimento_lengruber_1887015_dsc0000_3. Fundação D. João VI/Nova Friburgo.

${ }^{64}$ MARQUESE, Rafael de Bivar. A dinâmica da escravidão no Brasil: resistência escrava, tráfico negreiro e alforrias, séculos XVII a XIX. Novos Estudos. Volume 4. Cebrap: São Paulo, 2006; SALLES, Ricardo. Eo Vale era o escravo: Vassouras, século XIX. Senhores e escravos no coração do Império. Rio de Janeiro: Civilização Brasileira, 2008; MARQUESE, Rafael e TOMICH, Dale. "O Vale do Paraíba escravista e a formação do mercado mundial do café no século XIX.” In. MUAZE, Mariana e SALLES, Ricardo (Org.). 0 Vale do Paraíba e o império do Brasil nos quadros da segunda escravidão. Rio de Janeiro: 7 Letras, 2015. Sobre Friburgo e região ver: MARRETTO, O opulento capitalista...op. cit.
}

${ }^{65}$ MATTOS, op. cit;; MATTOS e GONÇALVES, op. cit. 
em suas principais atividades econômicas, Pedrosa pode ser entendido como um negociante-fazendeiro, alguém que buscava ascender socialmente e que expressava essa intenção na aquisição fundiária. ${ }^{66} \mathrm{E}$, no que se refere ao seu patrimônio, ele ainda se enquadraria no grupo das "grandes/ pequenas fortunas" do século XIX. ${ }^{67}$

Outrossim, sem entrar em um debate amplo sobre as bases teóricas que orientam cada uma dessas visões, entende-se, aqui, que Pedrosa também poderia ser percebido como membro de uma certa nobreza agrária. A historiografia do período colonial chamou a atenção para o fato de grandes proprietários e membros da Câmara Municipal fazerem parte de uma "nobreza da terra" que, mesmo sem ser titulada de direito, distinguia-se do restante da sociedade. A partir disso, os pesquisadores demonstraram o papel do grupo na construção e funcionamento do Império Português. ${ }^{68}$ Já os estudiosos do período imperial destacaram como o conceito de nobreza passou a ser, desde a vinda da família Real, bem mais circunscrito, relacionando-se àqueles que possuíam juridicamente distinção nobiliárquica recebida pela monarquia por meio de títulos ou comendas. ${ }^{69}$ Corroborando essa posição, defende-se a possibilidade de a expressão "nobreza agrária" servir de base para a análise de proprietários rurais que, apesar de não possuírem títulos e/ou condecorações, distinguiam-se, por seus hábitos, dos demais grupos sociais. ${ }^{70}$ Ou seja,

\footnotetext{
${ }^{66}$ FRAGOSO, Os barões... op. cit., 2013.

${ }^{67}$ Grupo que teve seus bens avaliados entre 50:000\$000 e 200:000\$000 réis. MATTOSO, Kátia M. de Queirós. Bahia, século XIX: uma província do Império. Rio de Janeiro: Nova Fronteira, 1992. João Bazet, médico e político local, cujo inventário somava 83:092 $\$ 000$ réis, foi classificado desta forma. Cf. MARRETTO, Rodrigo Marins. "Migrantes do império do Brasil: a trajetória de Jean Bazet nas origens da Vila de Nova Friburgo, 1820-1858". Saeculum. João Pessoa, v. 33, jul-dez.2015, p. 13-30.

${ }^{68}$ FRAGOSO, João; BICALHO, Maria Fernanda; GOUVÊA, Maria de Fátima (Orgs.) O Antigo Regime nos Trópicos: a dinâmica imperial portuguesa (séculos XVI-XVIII). Rio de Janeiro: Civilização Brasileira, 2001; MELLO, Evaldo Cabral. A fronda dos mazombos: nobres contra mascates, Pernambuco, 1666-1715. São Paulo: Editora 34, 2003. Para uma visão divergente sobre a importância da notoriedade local no processo de constituição da nobreza colonial ver: SILVA, Maria Beatriz Nilza da. Ser nobre na colônia. São Paulo: Unesp, 2005.

${ }^{69}$ SARAIVA, Luiz Fernando. O espaço da Nobreza: hierarquia e poder em Minas Gerais, no século XIX. Revista Maracanã. №19. Jul-Dez, 2018; GUIMARÃES, Lúcia. “Nobreza” In. VAINFAS, Ronaldo (Org.) Dicionário do Brasil Imperial. Rio de Janeiro: Objetiva, 2002, p. 553-555;

${ }^{70} \mathrm{~A}$ definição de nobreza presente no dicionário de Luis Pinto, publicado no século XIX, também fornece elementos para a construção dessa inferência. Segundo a obra, a palavra se refere tanto à "qualidade de nobre", como à "elevação de estillo", que, de acordo com o mesmo autor, tem como sinônimos, entre outros, "uso, ou costume". Se a primeira característica pode ser associada a alguma distinção legal (algo que está presente, no próprio dicionário, em uma das definições do que é " nobre"), a segunda parece ser bem menos específica e mais relacionada aos comportamentos dos agentes sociais. PINTO, Luiz Maria da Silva. Dicionario da língua brasileira. Ouro Preto, TYPOGRAPHIA DE SILVA, 1832, p. 59 e .94. Luiz Saraiva identificou tal situação neste e em outros dicionários do período. Contudo, o autor entende que o conceito, a partir de 1808, deve se circunscrever à nobreza titulada. SARAIVA, op. cit. Mesmo concordando com os argumentos,
} 
agentes que viviam, ou procuravam viver de fato, seguindo alguns valores da nobreza, dos melhores da terra, ou da boa sociedade em diversas regiões do Brasil, inclusive naquelas não destinadas à produção de gêneros de exportação, e que, por isso, podiam nem possuir um grande plantel de escravizados.

Diante do exposto, Dimas Ferreira Pedrosa apresentava três características que permitem o seu entendimento como membro de uma nobreza agrária local. A primeira se refere à sua vida política: ele foi vereador e presidente da Câmara durante alguns anos, ou seja, ele foi um "homem bom". ${ }^{71}$ A segunda se relaciona à posse de propriedades rurais, já que, mesmo endividado, terminou a vida sendo dono de 361 alqueires em uma região que não é caracterizada por latifúndios. A terceira, que será abordada agora, fundamenta-se nos padrões de comportamento que lhe conferiam alguma distinção social.

Nesse sentido, cabe citar que Pedrosa possuía em sua residência, na Vila de Nova Friburgo, um piano, algo que já foi salientado pela historiografia como um dos móveis que garantiam distinção na sociedade do Brasil Imperial. ${ }^{72}$ Além disso, ele investiu na educação do seu filho, matriculando-o no Colégio Pedro II, ${ }^{73}$ o que pode ser considerado um elemento de enobrecimento. Afinal, a maioria dos alunos do educandário era formada por filhos de grandes comerciantes da cidade do Rio e de membros da aristocracia rural, sendo, assim, o lugar daqueles que faziam parte da boa sociedade. ${ }^{74}$ Enquanto membro desse grupo, ele fez parte de comissões para arrecadação de fundos para reformas de igrejas, e, junto com o Barão de Nova Friburgo, de outra para arrecadar donativos para a construção de um monumento em homenagem a autores portugueses em Lisboa. ${ }^{75}$

Por fim, dois atos ocorridos após a morte de Dimas Ferreira Pedrosa ratificam a sua posição na sociedade friburguense: o seu enterro e o suicídio

e reconhecendo que a discussão aqui apresentada ainda é incipiente, a significação indicada por Pinto aponta para a possibilidade de um uso mais abrangente do vocábulo, mesmo no período pós-independência.

${ }^{71}$ NEVES, Guilherme Pereira. "Homens Bons" In. VAINFAS, Ronaldo (Org.) Dicionário do Brasil Colonial. Rio de Janeiro: Objetiva, 2000, pp. 284-286.

${ }^{72}$ MAUAD, Ana Maria. "Imagem e autoimagem do Segundo Reinado". In. ALENCASTRO, Luiz Felipe. (Org.) História da Vida Privada no Brasil, Vol. 2. São Paulo: Companhia das Letras, 2011.

${ }^{73}$ Seu nome aparece na convocação para exames no Colégio, em 1879 e 1881. A Gazeta de Notícias. Edição de 25 de agosto de 1879; Jornal do Comércio. Edição de 25 de julho de 1881. Hemeroteca Digital. Biblioteca Nacional. Disponível em: https://bndigital.bn.gov.br/hemeroteca-digital/ RJ. Acesso em 20/12/2020.

${ }^{74}$ GUIMARÃES, Lucia Bastos Pereira. “Colégio Pedro II” In VAINFAS, Ronaldo. (Org.) Dicionário do Brasil Imperial. Rio de Janeiro: Objetiva, 2002, p.347-348.

${ }^{75}$ Ver respectivamente: Correio Mercantil. Edição de 18 de julho de 1857; e Jornal do Comércio. Edição de 9 de novembro de 1877. Hemeroteca Digital. Biblioteca Nacional. Disponível em: https://bndigital.bn.gov. br/hemeroteca-digital/ RJ. Acesso em 20/12/2020. 
de seu filho. Em 18 de dezembro de 1882, ele foi velado na matriz de São João Batista de Nova Friburgo, aos 65 anos de idade, sendo, após a missa, acompanhado "solenemente" até o cemitério público, onde foi sepultado na quadra da prestigiada Irmandade do Santíssimo Sacramento. ${ }^{76}$ A probabilidade de o padrão de comportamento do fazendeiro-negociante ter sido afetada diante da crise econômica dos seus negócios e das dívidas não impediu a realização do velório e de um enterro com as pompas devidas ao seu status. Contudo, a perda das propriedades fez com que família tivesse que lidar com uma mudança na sua condição social, algo que o filho de Pedrosa não soube enfrentar.

Em 28 de julho de 1885, Dimas Ferreira Pedrosa, o filho, "em um acesso de loucura" cometeu suicídio na Fazenda Rio Grande. ${ }^{77} \mathrm{O}$ evento, noticiado em vários jornais da época, inclusive na capital, ressalta não somente o impacto do fato, como o destaque social que a família Pedrosa ainda possuía. ${ }^{78} \mathrm{~A}$ transcrição de uma carta deixada pelo morto à sua mãe ratifica o quão difícil seria para um homem, que outrora foi membro de certa nobreza agrária regional, gozando de algum padrão de vida aristocrático, viver sem dinheiro. Esta foi a justificativa do jovem, em missiva interessada a Antonio José Mendes, também grande proprietário na região:

Quando esta receberdes, estarei morto. Peço-vos de fazer o meu enterro, de cujas despesas deixo meu cunhado encarregado de vos pagar. Isso vos peço porque minha mãe é mulher e meu cunhado está em Friburgo, onde desejo ser enterrado, caso possa. Peço-vos também de levardes minha mãe para Friburgo, e mandar entregar quantos antes o embrulho que remeto a minha irmã. A causa da minha morte é o amor e não poder viver pobre. Perdoai-me senhor, esta fraqueza. E sou de VM atento, venerador, criado e obrigado. Dimas Ferreira Pedroza Filho. ${ }^{79}$

O fato de Pedrosa filho ter recorrido a Mendes se relaciona, possivelmente, à qualidade social do fazendeiro. ${ }^{80}$ Tal fato ainda é mais significativo tendo em vista que o pai do falecido e o destinatário do bilhete protagonizaram, nos

\footnotetext{
${ }^{76}$ Livro de Registro de Óbitos da Freguesia de São João Batista de Nova Friburgo, nº3 folha 200. Paróquia de São João Batista Nova Friburgo.

${ }^{77}$ Idem, folha 218.

${ }^{78}$ Diário de Notícias, Rio de Janeiro, 30 de julho de 1885, p.1. Hemeroteca Digital. Biblioteca Nacional. Disponível em: https://bndigital.bn.gov.br/hemeroteca-digital/ RJ. Acesso em 20/12/2020.

${ }^{79} \mathrm{O}$ PHAROL, Juiz de Fora, 01 de agosto de 1885, p.1. Hemeroteca Digital. Biblioteca Nacional. RJ. Disponível em: https://bndigital.bn.gov.br/hemeroteca-digital/ RJ. Acesso em 20/12/2020

${ }^{80}$ FRAZÃO, Um negociante... op. cit.
} 
anos 80 , disputas judiciais referentes a limites das suas propriedades ${ }^{81}$ Ao que parece, na ausência de seu pai, o proprietário vizinho foi tido como seu igual, ou seja, um dos poucos na região em que poderia confiar para auxiliar sua mãe no seu enterro. Essa autoimagem de um ex-nobre de estilo, ex-aluno do Colégio Pedro II, à beira da bancarrota, pode ser percebida, também, em outra carta, agora dirigida a sua mãe e publicada no mesmo jornal, dias depois, na qual o jovem corrobora o peso do desespero diante de uma nova condição social:

Mamãe. Eu queria me casar: precisava de uma fortuna para isto, porque a moça é rica; neste fim empreguei o dinheiro das madeiras em bilhetes de loteria, porém fui infeliz. Perdoai-me e abençoai-me. Sou seu filho, Dimas. ${ }^{82}$

Segundo o jornal, ele teria premeditado o crime, já que um dia antes do ocorrido havia acompanhado sua mãe até a casa de seu cunhado na Vila e se retirado para a fazenda sem comunicá-la. Uma vez chegado à propriedade, após escrever várias cartas, inclusive ao delegado de polícia, deu um tiro em seu próprio peito, no momento em que avistou a sua mãe que ia ao seu encontro.

Ainda que, no momento, não se tenha condições de averiguar a existência da relação amorosa, as palavras escritas pelo jovem dizem muito sobre a forma como ele se percebia e, consecutivamente, compreendia a situação da sua família. A conjuntura do suicídio, sua motivação e execução ratificam não somente a situação econômica complexa do clã, como a dificuldade do jovem em lidar com a sua nova posição social. Se vendo como filho de um dos "nobres" locais, ele não poderia seguir como um pobre sem terras. Suas palavras ratificam, assim, a posição ocupada por seu pai e pela família na sociedade friburguense, durante grande parte do século XIX.

\section{Considerações finais}

Ao longo das páginas anteriores, analisou-se a trajetória política, econômica e social de Dimas Ferreira Pedrosa, entendendo que, por meio dela, é possível caracterizar melhor as chamadas “Terras Frias” do Município de

\footnotetext{
${ }^{81}$ Processo de Dimas Ferreira Pedroza. Tribunal de Justiça do Rio de Janeiro (TJ-RJ). Acervo Permanente, caixa: 00591077-8.

${ }^{82}$ O PHAROL, Juiz de Fora, 04 de agosto de 1885, p2. Hemeroteca Digital. Biblioteca Nacional. RJ. Disponível em: https://bndigital.bn.gov.br/hemeroteca-digital/ RJ. Acesso em 20/12/2020
} 
Nova Friburgo. Baseando-se no referencial da história agrária, essa porção do território Fluminense foi compreendida enquanto uma região produtora de gêneros alimentícios e de criação de animais articulada a mercados locais e regionais. $\mathrm{O}$ fato de a área ser cortada por estradas que a conectavam com $\mathrm{o}$ centro da Vila, com Magé e com o Rio de Janeiro, ratificou a sua importância econômica. Viu-se que o clima frio, não tão propício ao cultivo do café, não impediu que vários imigrantes estrangeiros e de outras províncias do Império, como o próprio Pedrosa, instalassem-se ali a procura de oportunidades de geração de renda.

O mineiro Dimas Ferreira Pedrosa se envolveu em várias atividades que confirmam o cenário descrito. Iniciando a vida como negociante que supria as necessidades dos viajantes, foi adquirindo capital econômico e social. Em poucos anos, ele galgou o posto de fazendeiro ao mesmo tempo em que se tornou o presidente da Câmara dos Vereadores. Tendo como estratégia a pauta das estradas, conseguiu durante oito anos ocupar o posto de líder dos homens bons do município. Desde então, procurou consolidar a posição de membro da boa sociedade, aliando seus ganhos a um movimento contínuo de aproximação com o centro da Vila e de consolidação do seu status social. Notou-se que, em diversos momentos, ele dispendeu recursos necessários à manutenção da posição e que o auge do processo se deu nos 80, quando, bem perto do final de sua vida, ele comprou uma casa na praça principal da cidade.

Dessa forma, o negociante, que nunca deixou de ser fazendeiro, pôde ser percebido como um dos proprietários que pertenceriam a uma nobreza agrária local, ou seja, um grupo que, apesar de não possuir títulos nobiliárquicos, detinha prestígio social. Esse argumento se sustentou na apreciação de sua vida política e de suas ações econômicas e no exame de fatos que ocorreram a após a sua morte. Destacou-se, assim, principalmente, o suicídio de seu filho, que não sabia viver na pobreza. As cartas deixadas pelo jovem trazem à tona a mentalidade de um sujeito que sabia da perda da sua posição social. Suas palavras confirmam o prestígio e importância que a família auferia diante da sociedade local, o que ratifica a ideia de seus membros serem pensados como integrantes de uma nobreza agrária.

Por fim, tem-se ciência que ainda há muito a ser feito. 0 estudo de outros traços da vida de Dimas Ferreira Pedrosa e de outros proprietários locais já identificados ajudará a entender outras nuances da organização econômica e social das “Terras Frias". De antemão, torna-se mister o aprofundamento da análise das relações de produção e, principalmente, do uso da mão de obra 
escravizada naquele território. Se a biografa de Pedrosa permitiu uma reflexão inicial sobre o tema, o exame de outros fazendeiros ajudaria na percepção de novos aspectos, como o padrão das escravarias. Há ainda que se escrutinar a importância da produção de batata e os impactos da sua derrocada para a economia das "Terras Frias". Ou seja, fica clara, assim, a necessidade de outras histórias.

\section{Referências}

ARAÚJO, João Raimundo de; LO BIANCO, Regina; COSTA, Ricardo Rosa da Gama (Org.) Teia Serrana II: novos temas e novas abordagens. Nova Friburgo: Marca Gráfica Editora, 2019.

ARAÚJO. João Raimundo. A construção do mito da suiça (1910-1960). 2003. Tese (Doutorado em História) - Universidade Federal Fluminense, Niterói (RJ).

BARTH, Fredrik. Scale and Social Organization. Oslo: Universitetforlaget, 1978.

BOURDIEU, Pierre. O poder simbólico. Rio de Janeiro: Bertrand, 2010.

CARDOSO. Ciro Flamarion Santana. Agricultura, escravidão e capitalismo. Petrópolis: Vozes, 1979.

CASTRO, Hebe Maria Mattos de. Ao Sul da História: lavradores pobres na crise do trabalho escravo. Rio de Janeiro: Editoria FGV, 2009.

CERTEAU, Michel. A invenção do cotidiano. Vol. 1: Artes de fazer. Petrópolis, RJ: Vozes, 2008.

CORRÊA, Maria Janaína Botelho e SANTOS, Selmo de Oliveira. "Terras Frias: um ensaio sobre a reforma agrária na fazenda Rio Grande." In. ARAÚJO, João Raimundo de; LO BIANCO, Regina; COSTA, Ricardo Rosa da Gama (Orgs.) Teia Serrana II: novos temas e novas abordagens. Nova Friburgo: Marca Gráfica Editora, 2019, p. 105-129.

COSTA, Ricardo Gama da Costa e Guimarães, Fernanda. (Orgs.) Memórias do legislativo Friburguense: 200 anos de história da Câmara Municipal. Nova Friburgo: Gráfica Associação de Pais e Amigos dos Excepcionais, 2020.

DÁLIA, Jaqueline de Moraes Thurler. Aspectos fonéticos da variação linguísticaidentitárias das comunidades rurais do $3^{\circ}$ Distrito de Nova Friburgo-RJ. A cor das Letras, Feira de Santana (BA), v. 19, n. Especial, p. 40-63, mar. 2018. Disponível em: http://periodicos.uefs.br/index.php/acordasletras/article/view/2858. Acesso em: 20 agosto de 2020 . 
FARIA, Sheila de Castro. A colônia em movimento: fortuna e família no cotidiano colonial. Rio de Janeiro: Nova Fronteira, 1998;

FARIA, Sheila de Castro. Terra e trabalho em Campos dos Goitacases (1850-1920). 1986. Dissertação (Mestrado em História) - Universidade Federal Fluminense, Niterói;

FARIA. Sheila de Castro. "Ouro, porcos, escravos e café: as origens das fortunas oitocentistas em São Pedro de Cantagalo, Rio de Janeiro (últimas décadas do século XVIII e primeiras do XIX)". Anais do Museu Paulista. São Paulo, Nova Série, v.26, 2018, p. 1-23.

FÉO, Roberto. Raízes de Teresópolis: outras histórias e outras coisas. Teresópolis: Zen, 2010.

FERREIRA, Marieta de Moraes. História de famílias: casamentos, alianças e fortunas. Rio de Janeiro: Léo Christiano, 2008.

FILHO, Heitor Plínio de Moura. Câmbio de longo prazo do mil-réis: uma abordagem empírica referente às taxas contra a libra esterlina e o dólar (1795-1913). Cadernos de História, Belo Horizonte, v. 11, n. 15, jul.-dez. 2010, p. 9-34. Disponível em: http://periodicos.pucminas.br/index.php/cadernoshistoria/article/view/P.22378871.2010v11n15p9. Acesso em: 20 dezembro de 2020.

FRAGOSO, João. Homens de Grossa Ventura: acumulação e hierarquia na praça mercantil do rio de Janeiro (1790-1830). Rio de Janeiro/FAPERJ/Jorge Zahar Editor, 2008.

FRAGOSO, João. Os barões do café e o sistema agrário escravista: Paraíba do Sul/Rio de Janeiro (1830-1888). Rio de Janeiro: 7 Letras, 2013.

FRAGOSO, João; BICALHO, Maria Fernanda; GOUVÊA, Maria de Fátima (Orgs.) 0 Antigo Regime nos Trópicos: a dinâmica imperial portuguesa (séculos XVI-XVIII). Rio de Janeiro: Civilização Brasileira, 2001.

FRANCO, Maria Sylvia de Carvalho. Homens livres na ordem escravocrata. São Paulo: UNESP,1997. LENHARO, Alcir. As Tropas da Moderação. O Abastecimento da Corte na Formação Política do Brasil - 1808-1842. Rio de Janeiro: Prefeitura da Cidade do Rio de Janeiro, 1992.

FRAZÃO, Gabriel Almeida. "A Serviço da Formação do Jovem Rural”: Desafios e Contradições na Atuação do CEFFA CEA Rei Alberto I Como Agente do Desenvolvimento do Meio. 2015. Tese (Doutorado em Sociologia Rural) - Programa de Pós-graduação de Ciências Sociais em Desenvolvimento, Agricultura e Sociedade, Universidade Federal Rural do Rio de Janeiro, Seropédica (RJ). 
FRAZÃO, Gabriel Almeida. "Caminhos e descaminhos de um político local: considerações sobre as estratégias e a trajetória de Dimas Ferreira Pedrosa (Nova Friburgo - 1844-1882).”. In. COSTA, Ricardo Gama da Costa e Guimarães, Fernanda (Orgs). Memórias do legislativo Friburguense: 200 anos de história da Câmara Municipal. Nova Friburgo: Gráfica Associação de Pais e Amigos dos Excepcionais, 2020, p. 75-95.

FRAZÃO, Gabriel Almeida. Um negociante das -Terras Frias-: uma análise das estratégias de aquisição fundiária do português Antonio José Mendes (Nova Friburgo, 1860-1914). REVISTA MARACANAN, v. 1, p. 59-82, 2020.

GINZBURG, Carlo. Mitos, emblemas, sinais: morfologia e história. São Paulo: Companhia das Letras, 1989.

GUIMARÃES, Lucia Bastos Pereira. “Colégio Pedro II" In VAINFAS, Ronaldo. (Org.) Dicionário do Brasil Imperial. Rio de Janeiro: Objetiva, 2002, p.347-348.

GUIMARÃES, Lúcia Bastos. "Nobreza” In. VAINFAS, Ronaldo (Org.) Dicionário do Brasil Imperial. Rio de Janeiro: Objetiva, 2002, p. 553-555;

ISOLDI, Maria Celma Exner Godoy e FILHO, Carlos Alberto da Silveira Isoldi. Algumas famílias povoadoras do Alto do Rio das Velhas: Ferreira Pedrosa, Aguiar, Pereira Lima e Rodrigues Peixoto, p. 291. Revista da ASBRAP, n.26, 2019. Disponível em: www.asbrap.or.br/documentos/revistas/rev_26_2019/k-algumas_ familias_povoadoras_do_alto_rio_das_velhas_isoli.pdf Data de acesso 24/02/2020.

LEVI, Giovanni. A herança imaterial: trajetória de um exorcista no Piemonte do século XVII. Rio de Janeiro: Civilização Brasileira, 2000.

LIMA, Daniel Leite. Carmo no Século XIX: o arraial, a vila, e a cidade oitocentista de Nossa Senhora do Monte do Carmo. Gráfica e Editora Ried LTDA. 2º Edição: Rio de Janeiro: 2020, p. 467-478.

LINHARES, Maria Yeda e SILVA, Francisco Carlos Teixeira. História da Agricultura Brasileira: combates e controvérsias. São Paulo: Brasiliense, 1981.

LISBOA, Edson Castro. Café e escravidão em Nova Friburgo no século XIX. In: MAYER. Jorge Miguel; ARAÚJO, João Raimundo (Orgs.). Teia Serrana: formação histórica de Nova Friburgo. Rio de Janeiro: Editora ao Livro Técnico, 2003, p. 81-105.

MACHADO, Marina Monteiro. Entre fronteiras: posses e terras indígenas nos sertões (Rio de Janeiro, 1790-1824). Guarapuava, RJ: Unicentro, 2012. 
MARQUESE, Rafael de Bivar. A dinâmica da escravidão no Brasil: resistência escrava, tráfico negreiro e alforrias, séculos XVII a XIX. Novos Estudos. Volume 4. Cebrap: São Paulo, 2006.

MARQUESE, Rafael e TOMICH, Dale. "O Vale do Paraíba escravista e a formação do mercado mundial do café no século XIX.” In. MUAZE, Mariana e SALLES, Ricardo (org.). O Vale do Paraiba e o império do Brasil nos quadros da segunda escravidão. Rio de Janeiro: 7 Letras, 2015.

MARRETO, Rodrigo Marins. "Insurgência Escrava na Vila de Nova Friburgo (18201850)”. In ARAÚJO, João Raimundo de; LO BIANCO, Regina; COSTA, Ricardo Rosa da Gama (Org.) Teia Serrana II: novos temas e novas abordagens. Nova Friburgo: Marca Gráfica Editora, 2019, p. 77-104.

MARRETO, Rodrigo Marins e FRAZÃO, Gabriel Almeida. ““"Em benefício da elegância e a salubridade pública": Jean Bazet e a boa sociedade imperial na vila de Nova Friburgo (1828-1852).” In. COSTA, Ricardo Gama da Costa e Guimarães, Fernanda (Orgs). Memórias do legislativo Friburguense: 200 anos de história da Câmara Municipal. Nova Friburgo: Gráfica Associação de Pais e Amigos dos Excepcionais, 2020, p. 57-74.

MARRETTO, Rodrigo Marins. "Migrantes do império do Brasil: a trajetória de Jean Bazet nas origens da Vila de Nova Friburgo, 1820-1858”. Saeculum. João Pessoa, v. 33, jul-dez.2015, p. 13-30.

MARRETTO, Rodrigo Marins. A escravidão velada: senhores e escravos na formação da Vila de São João Batista de Nova Friburgo (1820-1850). Rio de Janeiro: Revan, 2018.

MARRETTO, Rodrigo Marins. O opulento capitalista: café e escravidão na formação do patrimônio familiar do Barão de Nova Friburgo. (1829-1873). 2019. Tese (Doutorado em História) - Universidade Federal Fluminense, Niterói (RJ).

MATTOS, Ilmar Rohloff e GONÇALVES, Márcia de Almeida. O Império da Boa Sociedade: a consolidação do Estado Imperial Brasileiro. São Paulo: Atual, 1991.

MATTOS, Ilmar Rohloff. O Tempo Saquarema: a formação do Estado Imperial. Rio de Janeiro: Acess, 1999.

MATTOSO, Kátia M. de Queirós. Bahia, século XIX: uma província do Império. Rio de Janeiro: Nova Fronteira, 1992. 
MAUAD, Ana Maria. “Imagem e autoimagem do Segundo Reinado”. In.

ALENCASTRO, Luiz Felipe. (Org.) História da Vida Privada no Brasil, Vol. 2. São Paulo: Companhia das Letras, 2011.

MAYER, Jorge Miguel. Raízes e crises do mundo caipira: o caso de Nova Friburgo. 2003. Tese (Doutorado em História) - Universidade Federal Fluminense, Niterói (RJ).

MAYER. Jorge Miguel; ARAÚJO, João Raimundo (Orgs.) Teia Serrana: formação histórica de Nova Friburgo. Rio de Janeiro: Editora ao livro Técnico, 2003.

MELLO, Evaldo Cabral. A fronda dos mazombos: Nobres contra mascates, Pernambuco, 1666-1715. São Paulo: Editora 34, 2003.

MOTTA, Márcia Maria Menendes. "História Agrária” In MOTTA, Márcia Maria Menendes (Org.). Dicionário da Terra. Rio de Janeiro: Civilização Brasileira, 2005, p. 239-240.

MOTTA, Márcia Maria Menendes. MOTTA. Nas fronteiras do poder: conflito e direito à terra no Brasil do século XIX. Niterói, RJ: EdUFF, 2008.

MOTTA, Márcia Maria Menendes. Pelas Bandas d'Além: fronteira fechada e arrendatários escravistas em uma região policultora. 1989. Dissertação (Mestrado em História) - Universidade Federal Fluminense, Niterói.

NEVES, Guilherme Pereira. "Homens Bons” IN. VAINFAS, Ronaldo (ORG.) Dicionário do Brasil Colonial. Rio de Janeiro: Objetiva, 2000, pp. 284-286.

OLIVEIRA, Victor Pereira. Repensando o rural sob o prisma das ruralidades, em Nova Friburgo, RJ. Curitiba: CRV, 2011.

PEDRO, José Carlos. A Colônia do "Morro Queimado": suiços e luso-brasileiros na Freguesia de São João Batista de Nova Friburgo (1820-31). 1999. Dissertação (Mestrado em História) - Universidade Federal Fluminense, Niterói (RJ).

PEDROZA, Manuela. Engenhocas da Moral: redes de parentela, transmissão de terras e direitos de propriedade na freguesia de Campo Grande (Rio de Janeiro, século XIX). Rio de Janeiro: Arquivo Nacional, 2011.

PROENÇA, Ane Thereza de Almeida. "Senhor vereador doutor: as frentes de atuação de Carlos Éboli na Câmara Municipal de Nova Friburgo." In. COSTA, Ricardo da Gama e GUIMARÃES, Fernanda. Memórias do legislativo Friburguense: 200 anos de história da Câmara Municipal. Nova Friburgo: Gráfica Associação de Pais e Amigos dos Excepcionais, 2020, p. 95-114. 
PRÓ-MEMÓRIA. Nova Friburgo: notas e informações. Nova Friburgo, RJ: Prefeitura Municipal de Nova Friburgo, 1985.

REVEL, Jacques (Org.). Jogos de escala: a experiência da microanálise. Rio de Janeiro: Ed. FGV, 1998.

SALLES, Ricardo. E o Vale era o escravo: Vassouras, século XIX. Senhores e escravos no coração do Império. Rio de Janeiro: Civilização Brasileira, 2008.

SAMPAIO, Sérgio Bittencourt. O Hotel Salusse em Nova Friburgo. Núcleo familiar, político e social. Rio de Janeiro: Imprimatur, 2009, p. 54.

SARAIVA, Luiz Fernando. O espaço da Nobreza: hierarquia e poder em Minas Gerais, no século XIX. Revista Maracanã. №19. Jul-Dez, 2018;

SILVA, Francisco Carlos Teixeira da. A formação social da miséria: Porto da Folha no sertão do São Francisco (1820-1920). 1ํEd. Rio de Janeiro: Autografia, 2018.

SILVA, Francisco Carlos Teixeira da; LINHARES, Maria Yedda. Região e história agrária. Estudos Históricos, Rio de Janeiro, v. 8, n. 15, p. 17-26, 1995.

SILVA, Maria Beatriz Nilza da. Ser nobre na colônia. São Paulo: Unesp, 2005.

Artigo recebido para publicação em 29/01/2021

Artigo aprovado para publicação em 16/08/2021 